\author{
dr Dorota JEGOROW \\ Wydział Nauk Społecznych, Katolicki Uniwersytet Lubelski Jana Pawła II \\ e-mail: dorotajegorow@kul.pl
}

DOI: $10.15290 /$ ose.2017.06.90.08

\title{
KREACJA PRZEDSIĘBIORCZOŚCI ZALEŻNEJ OD FUNDUSZY PUBLICZNYCH (WYBRANE ASPEKTY I PRZYKŁADY)
}

\begin{abstract}
Streszczenie
Celem niniejszego opracowania teoriopoznawczego jest wskazanie związku między rozwojem przedsiębiorczości a dostępem do subsydiów publicznych. Polska praktyka gospodarcza dostarcza licznych dowodów na to, że dostęp do szerokiego spektrum bezzwrotnych środków pomocowych przeznaczanych zarówno na realizację zadań publicznych, jak i dofinansowanie prywatnej działalności komercyjnej wpłynął na wykształcenie nowej formy aktywności gospodarczej w ramach „przedsiębiorczości zależnej” od zewnętrznych subsydiów. Studia literaturowe połączone $z$ analizą ilościową świadczą o tym, że jest to problematyka mająca wyraźnie ekspansywne przełożenie na praktykę gospodarowania, a jednocześnie charakteryzuje się deficytem naukowego rozpoznania. Zaprezentowana analiza wpisuje się w nurt rozważań współczesnej ekonomii w ramach instytucjonalnych uwarunkowań gospodarki.
\end{abstract}

Słowa kluczowe: przedsiębiorczość zależna, fundusze europejskie, fundusze publiczne

\section{CREATION OF ENTREPRENEURSHIP DEPENDENT ON PUBLIC FUNDS: SELECTED ASPECTS AND EXAMPLES}

\begin{abstract}
Summary
The aim of this paper is to show the relationship between the development of entrepreneurship and access to public subsidies. Polish economic practice provides evidence that access to a wide range of non-refundable aid, earmarked for the execution of tasks of public and private activity, gave rise to a new form of economic activity within the "entrepreneurship subsidiary" of external subsidies. Literature studies combined with quantitative analysis indicate that although the issue is of great interest among the potential beneficiaries of the wide range of offered subsidies, it is at the same time characterized by a deficit of scientific diagnosis. The presented analysis is part of the modern economic debate on the institutional framework of the economy.
\end{abstract}

Key words: entrepreneurship subsidiary, EU funding, public funds

JEL Classification: H23, L23 


\section{Wstęp}

Dążenie do zbudowania sprawiedliwego świata jest wpisane w bogaty dorobek deklaracji i czynów. Tymczasem, pomimo wyraźnego postępu w rozwoju cywilizacyjnym, licznych programów pomocowych obejmujących kwestie nierówności społecznych, problematyka ta jest jednym z najważniejszych wyzwań współczesnego świata. Dążenie do niwelowania nierówności to domena tak rządów państw narodowych, bloków państw, jak i organizacji ponadnarodowych. Nierówności indywidualne i zbiorowe znajdują się w centrum zainteresowania współcześnie rządzących zarówno tych reprezentujących sektor publiczny, jak i prywatny. Niezwykle ważnym instrumentem są w tym przypadku fundusze publiczne. Środki te są przeznaczane na realizację podstawowych usług, których gwarantem jest państwo, takich jak np.: edukacja, opieka zdrowotna, pomoc społeczna czy kultura, a jednocześnie stanowią istotny instrument rozwoju gospodarczego, a w tym stymulowania przedsiębiorczości.

Polska przestrzeń publiczna, a zatem również i gospodarka, w minionym ćwierćwieczu została wkomponowana w nowe instytucje i koncepcje rozwoju, w tym zasady finansowania zadań publicznych oraz przedsiębiorczości indywidualnej. Nowe regulacje sprawiły, że liczne obszary aktywności gospodarczej zarezerwowane dotychczas dla instytucji państwa, jak chociażby edukacja czy podstawowa opieka zdrowotna, mogły być organizowane przez instytucje funkcjonujące w ramach sektora prywatnego. Dodatkowo, sytuacja ta została wzmocniona wysokim napływem funduszy pomocowych, wpisanych w polityki rozwojowe Unii Europejskiej. Począwszy od 1 maja 2004 roku, do Polski trafiło 130 mld euro funduszy europejskich [Zestawienie transferón finansonych..., 2016].

Celem niniejszego opracowania teoriopoznawczego o charakterze teoretyczno-praktycznym jest próba wyodrębnienia i dookreślenia nowej formy aktywności gospodarczej funkcjonującej w ramach ,przedsiębiorczości zależnej” od zewnętrznych subsydiów. Główną determinantą zidentyfikowanego rodzaju działalności jest dostęp do szerokiego spektrum bezzwrotnych środków pomocowych zagospodarowywanych w równej mierze na realizację zadań publicznych, jak i dofinansowanie prywatnych inicjatyw o charakterze komercyjnym. Kluczowy problem badawczy sprowadza się do identyfikacji zasadniczych obszarów aktywności społeczno-gospodarczej, w których występuje zjawisko przedsiębiorczości zależnej. Studia literaturowe połączone z obserwacją oraz uproszczoną analizą ilościową (stanowiącą symboliczną ilustrację zrealizowanych badań opartą na własnych analizach wtórnych źródeł danych $i$ wynikach zaczerpniętych z innych opracowań) wskazuja, że jest to problematyka mająca wyraźnie ekspansywne przełożenie na praktykę gospodarowania, a jednocześnie cechuje się deficytem naukowego rozpoznania. Teoria rozwoju gospodarczego Schumpetera wprawdzie nie daje podstaw do postrzegania podjętej tematyki jako oryginalnej, jednak pozwala na jej pozytywną walidację. 


\section{Fundusze publiczne jako źródło finansowania podmiotów z sektora prywatnego}

Trwający w przestrzeni publicznej żywiołowy dyskurs nad optymalnym modelem gospodarowania jednostek i zbiorowości spowity jest ogromem teorii i formułowanymi na ich gruncie rekomendacjami. Bogaty dorobek literatury ekonomicznej z przełomu XX i XXI wieku wraz z definiowanymi aktualnie problemami rozwojowymi skłaniaja do głębokiej refleksji nad potrzebą odejścia od uproszczonej teorii wyboru wpisanej w ograniczone zasoby ku logice tworzenia form koordynacji społecznej z uwzględnieniem aspektu umiejętności i woli współdziałania ludzi [Godłów-Legiędź, 2010, s. 166-167]. W kontekście tych dylematów poznawczych niezwykle ważne miejsce odgrywa nowa ekonomia instytucjonalna oraz ekonomia sektora publicznego, a zatem układ formalno-instytucjonalny będący domeną państwa.

Aktualnie kompetencje władzy administracyjnej obejmuja przede wszystkim pobór indywidualnych efektów pracy, ich podział oraz redystrybucję. Każdy z tych wymiarów jest niezwykle ważny w zakresie oceny sprawności funkcjonowania gospodarek jako całości. Istotną determinantą sprawności każdego systemu ekonomicznego jest jego spójność instytucjonalna. Choć model oparty na decentralizacji władzy i kompetencji zaprzecza temu postulatowi, to ma on bardzo wielu zwolenników. Tymczasem jedną z wielu kwestii wymagających rozpoznania naukowego nadal pozostaje identyfikacja i pomiar efektywności sektora publicznego, co docelowo należy łączyć z pożądanym, „lepszym" wykorzystaniem zasobów [Miłaszewicz, 2014, s. 171; Skica, 2010, s. 128; Stankiewicz, 2012, s. 234-235; Woźniak, 2009, s. 40]. Jednocześnie nieustannie trwają dyskusje nad wyznaczaniem dopuszczalnych granic oddziaływania państwa na gospodarkę. Głównym przedmiotem sporu jest niejednorodne postrzeganie roli państwa, mające zabarwienie ideowego i politycznie normatywnego podejścia do tego zagadnienia [Miłaszewicz, 2005, s. 73]. Natomiast najnowsze wnioski płynące z badania krajowych barier i warunków dostosowań instytucjonalnych nie napawają optymizmem. Dzieje się to m.in. za sprawa dekad bezwiednego wdrażania rozwiązań szkoły neoliberalnej przy jednoczesnej decentralizacji władzy publicznej oraz nadmiernego przenikania się sfery stanowienia prawa i zarządzania państwem [Godłów-Legiędź, 2017, s. 6; Woźniak, 2017, s. 24-26]. W stworzonych warunkach zarządzanie sektorem publicznym, w tym jego finansami, nabrało nowego znaczenia. Ogół powyższych obszarów problemowych generuje złożoną strukturę. Znaczną jej część wypełnia zagadnienie efektywności ekonomicznej przedsięwzięć finansowanych ze środków publicznych. Postępująca ekonomizacja działań państwa formalnie odbiega od poglądu wpisanego w główny nurt ekonomii, a głoszącego, że dobra publiczne powinny być dostarczane przez sektor publiczny [Kargol-Wasiluk, 2008, s. 111].

Wzajemne przenikanie się wpływów i zadań łączących poszczególne sektory gospodarki niesie ze sobą zarówno szanse, jak i zagrożenia. Jedną z nich jest subwencjonowanie zadań publicznych [Stiglitz, 2004, s. 241]. Współcześnie problem ten należy rozpatrywać w szerszym ujęciu obejmującym podmioty prywatne będące biorcami subwencji lub dotacji publicznych przeznaczanych na finansowanie zadań tak o charakterze podstawowym, jak i prorozwojowym, lecz każdorazowo określonych przez państwo. 
Zmiana struktury własnościowej podmiotów gospodarki narodowej oraz przeniesienie licznych obszarów zarezerwowanych wcześniej wyłącznie dla działalności instytucji funkcjonujących w ramach struktur państwowych, a w końcu akcesja Polski do Unii Europejskiej otworzyły liczne, nowe możliwości aktywności komercyjnej zasilanej funduszami publicznymi. Ogół nowych perspektyw instytucjonalnych i finansowych przełożył się na strukturalne zmiany krajowej gospodarki, u podłoża których leżą przekonania wolnorynkowe, a w szczególności zapewnienie konkurencji gwarantującej atrakcyjną cenę i wysoką jakość oferowanych towarów i usług. Spory o to, jak organizować gospodarkę w zakresie obszarów, których gwarantem jest państwo, wpisują się w jedne z ważniejszych dylematów współczesnej ekonomii. Jednak żywiołowym dyskusjom nie towarzyszy konsensus poznawczy $\mathrm{i}$ interpretacyjny.

Wkraczanie władzy publicznej w sferę realnej gospodarki to nie tylko tworzenie regulacji, ale również włączanie środków publicznych w finansowanie przedsięwzięć gospodarczych. Obecnie na krajowym rynku nie brakuje: niepublicznych zakładów opieki zdrowotnej, niepublicznych placówek opiekuńczych, wychowawczych i edukacyjnych, a w końcu wielu nowych firm, które powstały przy znaczącym wsparciu środków przyznanych na prowadzenie działalności gospodarczej czy firm, które w ramach dostępnych funduszy europejskich zmodernizowały lub zdywersyfikowały prowadzoną działalność. W każdym z wyżej wymienionych przypadków źródłem aktywności biznesowej w znaczącej części były fundusze publiczne.

W odniesieniu do celowo powoływanych ośrodków, realizujących zadania z zakresu opieki społecznej, zdrowotnej czy edukacyjnej, należy wskazać względną trwałość podmiotów, co wprost wynika z modelu dotacyjnego wpisanego w system funduszy publicznych. Dopuszczalna w wielu przypadkach mieszana forma finansowania prowadzonej działalności, włączająca możliwość zagospodarowywania środków prywatnych pochodzacych od usługobiorców, w praktyce wyrównuje w wielu sytuacjach szanse konkurowania z podmiotami publicznymi, które w razie nadwyżki kosztów nad przychodami są zasilane dodatkowymi środkami publicznymi, ewentualnie powstają lub zwiększają się zobowiązania publiczne. Nie brakuje bowiem przykładów, w których z założenia podmioty prywatne otrzymaja zmniejszone wsparcie finansowe na realizację tego samego zadania, co podmioty publiczne. Dzieje się tak m.in. w edukacji przedszkolnej. Dotacja dla prywatnych placówek wynosi 75\% kosztów, jakie gmina ponosi na jednego ucznia w placówce samorządowej' ${ }^{1}$ O ile placówka niepubliczna może żądać dodatkowych opłat mających charakter podstawowy, o tyle placówki publiczne takiego prawa nie maja. Rozwiązanie to nie jest jednak powszechne i warunkowane jest zarówno urbanizacja, jak i uprzemysłowieniem poszczególnych jednostek przestrzenno-administracyjnych. Odrębną kwestią jest zatem dyskryminacja podmiotów świadczących tożsame usługi wpisane w równej mierze w domenę publiczną, jak i prywatną. Z drugiej strony należy podkreślić, że obowiązujące regulacje prawne w wielu przypadkach ograniczają podmioty publiczne w zdobywaniu dodatkowych środków finansowych, faworyzując tym samym podmioty prywatne, co ma m.in. miejsce w opiece medycznej.

Art. 14 Ustany z dnia 13 czerwca 2013 roku o zmianie ustany o systemie oświaty oraz niektórych innych ustaw (Dz. U. 2013, poz. 827 z późn. zm.), a od 1 września 2015 roku art. 90 ust. 2d Ustany z dnia 13 czerwica 2013 roku o zmianie ustany o systemie ośniaty oraz niektórych innych ustaw (Dz. U. poz. 827 z późn. zm.). 
Wprowadzenie możliwości finansowania podmiotów prywatnych prowadzących działania publiczne, w szczególności te, których gwarantem jest państwo, spowodowało wykształcenie nowego rodzaju struktur organizacyjnych o charakterze quasi-prywatnym. Niezależna struktura własnościowa gwarantuje większy poziom elastyczności podziału środków pomocowych w porównaniu z podmiotami funkcjonującymi w sferze publicznej. Zasadniczą kwestia jest w tym przypadku podział wynagrodzeń niejednokrotnie charakteryzujący się bardzo wyraźną asymetrią prawostronna, warunkowana jednoznacznym nastawieniem na zysk inicjatorów prowadzonej działalności. $\mathrm{Na}$ tym polu wyłania się kolejny bardzo ważny problem rażących dysproporcji pracy i płacy między sektorem prywatnym a publicznym w ramach tych samych zadań publicznych.

W realizacji zadań finansowanych ze środków publicznych, w tym europejskich, będących podstawowym wymiarem działalności danego podmiotu gospodarczego nadrzędnym celem staje się zagospodarowywanie pozyskanych dotacji, a nie realizacja zadań wpisanych w fundusze pomocowe. Problem narasta, gdy subsydia stają się trwałym i niemal wyłącznym warunkiem funkcjonowania podmiotu. Podobne zasady obowiązują w zdobywaniu zamówień publicznych wymagających specjalizacji i doświadczenia, ale niekoniecznie posiadania zaplecza technicznego. W istocie ubieganie się o dotacje celowe, subwencje oraz pozostałe środki w ramach polityki spójności są zbliżone do aplikowania o wszelkie inne zamówienia publiczne. W przypadku, gdy wspólnym elementem ogółu zamówień jest wyłączność sektora publicznego jako zleceniodawcy, należy mówić o występowaniu specyficznej zależności.

Abstrahując od charakteru zadań realizowanych przez podmioty prywatne, uzależnienie od transferów finansowych płynących z sektora publicznego należy postrzegać w wymiarze realizacji doraźnych lub względnie trwałych projektów. W kompetencjach właścicieli lub organów zarządczych podmiotów otrzymujących subsydia pozostaje właściwe rozliczanie przyznanych środków. Oczywiście nie oznacza to marginalizowania jakości zlecanych zadań, gdzie w wielu przypadkach dochodzi do w pełni racjonalnych rozwiązań generujących wysokiej jakości usługi lub produkty. Problemem jest weryfikacja rozwiązań mających wymiar niematerialny, wśród których zazwyczaj opiera się ona na dokumentacji operacyjno-finansowej bądź techniczno-finansowej.

Kultura tworzenia podmiotów gospodarczych opartych na schemacie przedsiębiorczości zależnej jest w Polsce rozwijana m.in. w ramach bezzwrotnych dotacji na rozpoczęcie działalności gospodarczej. Wiele przedsiębiorstw powstałych przy wsparciu funduszy publicznych nie przetrwało na rynku dłużej, niż to było założone w projekcie dotacyjnym, zarówno z powodu świadomego zagospodarowania możliwych do pozyskania środków, jak i w wyniku braku kompetencji pozwalających na prowadzenie przedsiębiorstwa czy świadomego budowania bytów nastawionych na przetrwanie, w praktyce zależnych od zewnętrznych transferów finansowych [jegorow, 2016, s. 70; 2017d, s. 74]. Fundusze publiczne, będące podstawowym źródłem finansowania podmiotów gospodarki rynkowej, niejednokrotnie stają się zatem celem gospodarowania zorientowanym na maksymalizację ich pozyskiwania. 


\section{Przedsiębiorczość zależna jako celowy model biznesowy}

Bogaty dorobek nauki ekonomii dostarcza wielu definicji przedsiębiorczości, jednak każdorazowo kładąc nacisk na tworzenie i wykorzystywanie szans rynkowych, jakie przejawiaja jednostki w trakcie swojej aktywności. Dominujący nurt współczesnych rozważań sprowadza przedsiębiorczość do najistotniejszych atrybutów rynkowego modelu gospodarowania [Glinka, Gudkova, 2011, s. 9, 11]. Aktualne postrzeganie przedsiębiorczości, co do istoty samej kategorii zorientowanej na indywidualne predyspozycje leżące u podstaw jednostki przedsiębiorczej, wpisuje się w utrwalone w nauce modele teoretyczne. Zmianie ulega podejście do kapitału finansowego i rzeczowego, niezbędnego do uruchomienia działalności gospodarczej. Wynika to tak samo z postępujacej informatyzacji i serwicyzacji gospodarki pozwalających na tworzenie rozwiązań, które nie wymagaja wysokich nakładów kapitałowych, jak i dywersyfikacji źródeł finansowania. W wielu przedsięwzięciach zaplecze finansowe nabiera drugorzędnego charakteru, choć nie oznacza to rezygnacji z możliwości zagospodarowywania dostępnych bezzwrotnych środków finansowych. Naturalną sytuacją jest to, że jednostki przedsiębiorcze, dostrzegając możliwość pozyskania funduszy pomocowych, odnosząc z tego faktu korzyść ekonomiczna, podejmują aktywność w tym zakresie.

Przedsiębiorczość zależna jako kategoria ekonomiczna jest nowym terminem na ogół kojarzonym z modelem angażowania kapitału społecznego w ramach większych jednostek gospodarczych. Rejestrowane w ramach tego typu zależności przedsiębiorstwa w praktyce maja charakter alternatywny do stosunku pracy. W istocie zatem dochodzi do pozornie niezależnej aktywności w ramach tworzonych przedsiębiorstw. Rozumiana w ten sposób kategoria przedsiębiorczości zależnej jest łączona m.in. z takimi przydawkami, jak: fałszywa, fikcyjna czy wymuszona [Cieślik, 2014, s. 49]. Kontraktowanie usług, wedlug opisanego schematu, wprawdzie nie jest w Polsce powszechne, ale systematycznie zyskuje na popularności. Ważkość problematyki i potrzeba prowadzenia badań empirycznych w tym zakresie jest podkreślana w analizach naukowych skupionych wokół tematyki samozatrudnienia. Kwestia przedsiębiorczości zależnej wiąże się w tym przypadku z działaniem mimowolnym lub też wymuszonym. Wskazywana jest również zbieżność z outsourcingiem [Kautonen, Down, Welter i in. 2010, s. 124-125]. Przedsiębiorczość zależna jest także utożsamiana z kryterium bezpośredniego inwestowania [Measuring Globalisation..., 2015, s. 60].

Zaprezentowane podejścia nie wyczerpują jednak istoty przedsiębiorczości zależnej, ponieważ zależność finansowa ma znacznie szerszy kontekst. Można zatem przyjąć, że przedsiębiorczość zależna powstaje m.in. na gruncie związku między instytucją finansująca a biorca funduszy pomocowych przeznaczonych na całkowite lub częściowe pokrycie kosztów realizacji zaplanowanego przedsięwzięcia. Spełnienie wymogów formalno-prawnych funkcjonowania podmiotu gospodarki narodowej w istocie nie oznacza więc funkcjonowania według ogółu zasad wyznaczonych przez teoretyczne ramy przedsiębiorczości. Zależność finansowa ma charakter przyczynowo-skutkowy, gdzie zarówno poprzednik, jak i następnik implikacji mogą występować w bardzo różnorodnej konfiguracji [Jegorow, 2017c, s. 139-148]. Tak rozumiana przedsiębiorczość zależna, 
pozbawiona względnie trwałych bezzwrotnych transferów finansowych płynących $z$ instytucji finansujących, w tym m.in. państwowych bądź samorządowych, nie utrzymałaby się na rynku. Zasadniczo zatem mowa w tym przypadku o quasiprzedsiębiorczości. Zagospodarowywanie środków wpisanych w bezzwrotne transfery finansowe przenosi kluczowy ciężar prowadzenia działalności do wymiaru administracyjno-rozliczeniowego. Nie w każdym przypadku dotowane obszary poddają się obiektywnie porównywalnej ocenie jakościowej, a dotyczy to podobnie edukacji, kultury, jak i opieki medycznej.

\section{Praktyka przedsiębiorczości zależnej wpisanej w publiczne transfery finansowe}

Twierdzenie, że niemal wszyscy uprawiaja „przedsiębiorczość, np.: lekarze, księża, profesorowie czy pracownicy instytucji charytatywnych, stało się domeną współczesnej przestrzeni społeczno-gospodarczej [Piecuch, 2013, s. 49]. Bynajmniej nie chodzi o wymiar formalny, ale przed wszystkim operacyjny związany z poszukiwaniem okazji do aktywności zawodowej. Liczne granty, datki, dotacje bądź subwencje tworzą z jednej strony system organizacyjny dotyczący pozyskiwania środków oraz ich redystrybucji, a z drugiej strony jest to pole wzmożonej aktywności w zakresie ubiegania się o ich otrzymanie, a następnie zagospodarowanie. Na tym tle szczególnego znaczenia nabieraja subwencje oraz dotacje, które w wielu przypadkach stają się celem gospodarowania zorientowanym na maksymalizację bezzwrotnych transferów, stanowiąc jednocześnie podstawowe źródło finansowania prowadzonej działalności. Przedsiębiorczość zależna stwarza szerokie spektrum możliwości obejmujących głównie te obszary, w których pomiar efektów został sprowadzony do wymiaru ilościowego, mierzonego wysokością dopłaty do określonego obiektu lub zdarzenia, bądź skwantyfikowanych wskaźników rezultatów zazwyczaj odnoszących się do produktów. W większości sytuacji wysokość finansowania jest wprost proporcjonalna do wykazanej grupy obiektów, na które przysluguje wsparcie (np.: „dopłata do hektara”, ,,subwencja na ucznia”, „, dotacja na pacjenta"). Tak rozumiana przedsiębiorczość zależna wpisuje się w poniższe, przykładowe kategorie, które nie mają charakteru rozłącznego, takie jak:

- $\quad$ edukacja (kształcenie dzieci i młodzieży w placówkach niepublicznych, które wchodzą w skład subwencji oświatowych);

- $\quad$ edukacja i wychowanie (ośrodki wychowawcze dla młodzieży, które wiążą się z subwencjami oświatowymi);

- $\quad$ kultura i sztuka (dotacje zarówno samorządowe, jak i rządowe dla wybranych instytucji lub do wybranych wydarzeń, w praktyce stanowiące dofinansowanie prywatnych podmiotów, takich jak. np. teatry);

- opieka społeczna (placówki opiekuńczo-wychowawcze finansowane przez samorządy);

- $\quad$ rolnictwo (dopłaty bezpośrednie do wielkości areału w ramach Wspólnej Polityki Rolnej);

- medycyna (usługi realizowane w ramach kontraktów z Narodowym Funduszem Zdrowia); 
- $\quad$ sport (kluby sportowe finansowane przez samorządy lub pozyskujące środki z programów rządowych);

- $\quad$ polityka (partie polityczne otrzymujące subwencje z budżetu państwa; po uzyskaniu odpowiedniego wyniku w wyborach do sejmu wymaga to jednak: w przypadku partii samodzielnie tworzącej komitet wyborczy co najmniej 3\% ważnie oddanych głosów na okręgowe listy kandydatów w skali kraju bądź 6\% ważnie oddanych głosów w skali kraju, jeżeli partia kandyduje w koalicji);

- $\quad$ rozwój lokalny (stowarzyszenia samorządów opłacane przez jednostki samorządu terytorialnego proporcjonalnie do liczby ludności zamieszkującej daną jednostkę przestrzenno-administracyjna);

- $\quad$ projekty europejskie (inicjatywy podejmowane wyłącznie w celu pozyskania i zagospodarowania dotacji gwarantującej wynagrodzenie dla liderów podmiotu będącego projektodawcą - beneficjentem pomocy, często pośrednikiem w redystrybucji planowych środków);

- $\quad$ podejmowanie działalności gospodarczej przez osoby bezrobotne (rejestracja podmiotu gospodarczego motywowana możliwością pozyskania dotacji, a niekoniecznie świadomością przedsiębiorczą wpisaną w trwałość rynkowa);

- $\quad$ sektor pozarządowy (zinstytucjonalizowany podwykonawca wielu zadań publicznych wykorzystujaccy preferencje organizacyjne i podatkowe, traktujący fundusze pomocowe jako warunek trwania).

Powyższy katalog nie wyczerpuje ogółu obszarów dotyczących modelu przedsiębiorczości zależnej, jak również nie obejmuje ogółu źródeł ich finansowania. Każdy z wyżej wymienionych przypadków jest złożony, a jednocześnie w nauce zazwyczaj jest rozpoznawany oddzielnie, zawężając tym samym rozważania prowadzone na gruncie ekonomii do konkretnego zakresu²

\section{Ilościowy wymiar przedsiębiorczości zależnej w wybranych branżach}

O atrakcyjności sektora powstałego w ramach przedsiębiorczości zależnej świadczy przyrost podmiotów podejmujących się aktywności gospodarczej we wcześniej wspomnianych obszarach. Nie bez przyczyny np. wielu mieszkańców miast wykupiło grunty rolne położone na terenach odległych od miejsca zamieszkania. W wielu przypadkach celem nie była zmiana wykonywanego zawodu czy też dywersyfikacja prowadzonej działalności zawodowej, a przede wszystkim możliwość zwiększenia własnych dochodów w ramach pozyskanych dotacji. Nie rezygnując z pracy zawodowej, niejedna osoba na przestrzeni minionej dekady zwiększyła swoje zarobki o dopłaty bezpośrednie do

2 Wskazane przypadki przedsiębiorczości zależnej nie są wyłącznie domeną gospodarki krajowej. Nie brakuje dowodów wskazujących np. na wyłącznie zarobkowy charakter tworzenia i utrzymywania obozów dla imigrantów we Włoszech czy funkcjonowania niemieckiego urzędu do spraw dzieci i młodzieży Jugendamt. Obie formy organizacyjne zostały powołane w odpowiedzi na zdiagnozowane problemy społeczne. Jednak praktyka ich funkcjonowania dowodzi, że nie zawsze chodzi o pomoc potrzebującym, a istotą ich bytu staje się jedynie utrzymanie instytucji finansowanych ze środków publicznych wprost proporcjonalnie do liczby zależnych beneficjentów. 
gruntów rolnych. Na zjawisko masowego wykupu ziemi istotny wpływ miał również znaczący napływ kapitału zagranicznego do Polski. Charakter dochodowy dopłat bezpośrednich wyraźnie zmarginalizował założony ich kompensacyjny charakter [Czubak, 2008, s. 118; Lipińska, 2010, s. 36; Sobiecki, 2015, s. 41-42]. W wielu przypadkach cel zakupu areału został połączony z poszukiwaniem dochodu pasywnego. Zidentyfikowaną korzyść należy łączyć z potencjalnym zagrożeniem wskazującym na to, że otraymywanie pieniedsy tylko z. tytutu posiadania ziemi prowadzi do demoralizacij (...) i może mié́ katastrofalne skutki w praysžłości [Jakimowicz, 2012, s. 476].

Nie bez znaczenia w rozpoznaniu problematyki przedsiębiorczości zależnej pozostaje to, że zainteresowanie prowadzeniem własnej praktyki lekarskiej wśród młodych pracowników ochrony zdrowia systematycznie wzrastało na przestrzeni ostatnich lat. Fakt ten należy łączyć z możliwością opłacania znaczącej części usług w ramach kontraktów z Narodowym Funduszem Zdrowia [Wyrozębska, Matysiak, Tatara i in. 2012, s. 319, 323]. Jednocześnie należy podkreślić, że wskaźnik przeżycia firm oferujących usługi $\mathrm{w}$ obszarze ochrony zdrowia w porównaniu z podmiotami reprezentującymi inne branże gospodarki w latach 2005-2010 był najwyższy [Wyrozębski, Wyrozębska, 2012, s. 118]. Ostatnie lata nie osłabiły trwałości rynkowej tego typu podmiotów, nadal plasując je w czołówce branż o najwyższych wskaźnikach przeżycia, osiagając na przełomie lat 2014-2013 wynik 88,1\% [Bank Danych Lokalnych, 2015, s. 46].

Dotowana przez państwo edukacja dzieci, młodzieży i dorosłych została również zręcznie zagospodarowana przez sektor prywatny. Przykładem jest w tym przypadku chociażby liczba prywatnych placówek oświatowych powstałych w minionym dwudziestoleciu. Udział szkół podstawowych dla dzieci i młodzieży (bez specjalnych) w rynku edukacyjnym w 1998 roku wynosił zaledwie 1,05\%, a w 2015 roku już 13,51\%. Z kolei, udział dzieci uczęszczających do tych placówek wzrósł z 0,45\% w 1998 roku do 5,19\% w 2015 roku [Bank Danych Lokalnych, 2016]. W obu przywołanych kategoriach ${ }^{3}$ ilościowych kierunek zmian skoncentrowanych na rozwoju przedmiotowych usług w ramach sektora prywatnego miał charakter jednoznacznie wzrostowy. Potwierdza to analiza korelacji ${ }^{4}$ wskazująca na wysoką i bardzo wysoką zależność przywołanych cech statystycznych ilustrujących edukację.

3 Wybór cech statystycznych (liczba oddziałów, liczba uczestników edukacji) został zdeterminowany dostępem do danych pozostających w ogólnie dostępnych zasobach statystyki publicznej. Zasoby te powinny zostać uzupełnione o informacje dotyczące wydatków ponoszonych na poszczególne formy kształcenia i źródeł ich finansowania. W szczególności należy uwzględnić zarówno fundusze publiczne, a zatem te pochodzące bezpośrednio z budżetu państwa, jak i te stanowiące dodatkowe obciążenie budżetów jednostek samorządu terytorialnego.

$4 \quad$ Wybór zastosowanych $\mathrm{w}$ analizie testów statystycznych wprost wynika z braku uniwersalnego narzędzia badawczego pozwalającego na jednoznaczne stwierdzenie występowania czy też braku zależności zestawionych cech statystycznych. Przyjęte rozwiązanie wynika dosłownie z niedoskonałości dostępnego instrumentarium badawczego. Biorąc pod uwagę instrumentarium narzędziowe związane $z$ badaniem korelacji, optymalnym rozwiązaniem jest stosowanie możliwie szerokiego zestawu testów. Rozwiązanie to znacząco uprawdopodabnia wynik mający nadal charakter szacunku. Zastosowane testy nie mają charakteru alternatywnego. Łączne ich użycie ma charakter uzupełniający, a docelowo jest zwiazzane z umocowaniem otrzymanych wyników poprzez zgodność poszczególnych testów. Przyjęta metodyka badawcza zwiększa szanse wykluczenia występowania zjawiska korelacji pozornej. Jest to 
TABELA 1.

Analiza korelacji wybranych cech statystycznych opisujących edukację podstawowa, opartych na szeregach czasowych obejmujących lata 1998-2015

\begin{tabular}{|c|c|c|c|c|c|c|}
\hline \multirow{9}{*}{\begin{tabular}{|l} 
Pearsona \\
\end{tabular}} & & & [1] & [2] & [3] & [4] \\
\hline & \multirow[t]{2}{*}[1]{} & WK & 1 & & & \\
\hline & & $p$ & & & & \\
\hline & \multirow[t]{2}{*}{\begin{tabular}{|l|}
{$[2]$} \\
\end{tabular}} & WK &,$- 670^{* *}$ & 1 & & \\
\hline & & $p$ &, 002 & & & \\
\hline & \multirow[t]{2}{*}{ [3] } & WK & ,956** &,$- 842^{* *}$ & 1 & \\
\hline & & $p$ & 000 &, 000 & & \\
\hline & \multirow[t]{2}{*}{ [4] } & WK &,$- 735^{* *}$ & ,990** &,$- 890^{* *}$ & 1 \\
\hline & & $p$ &, 001 &, 000 & 000 & \\
\hline \multirow[t]{8}{*}{ rho Spearmana ${ }^{6}$} & \multirow[t]{2}{*}[1]{} & WK & 1 & & & \\
\hline & & $\mathrm{p}$ & & & & \\
\hline & \multirow[t]{2}{*}{\begin{tabular}{|l|}
{$[2]$} \\
\end{tabular}} & WK &,$- 893^{* *}$ & 1 & & \\
\hline & & $p$ & 000 & & & \\
\hline & \multirow[t]{2}{*}{\begin{tabular}{|l|}
{$[3]$} \\
\end{tabular}} & WK &, $895^{* *}$ &,$- 998^{* *}$ & 1 & \\
\hline & & $p$ & 000 &, 000 & & \\
\hline & \multirow[t]{2}{*}{ [4] } & WK &,$- 895^{* *}$ & ,998** & $-1,000^{* *}$ & 1 \\
\hline & & $p$ &, 000 &, 000 & & \\
\hline \multirow[t]{8}{*}{ Tau b Kendalla } & \multirow[t]{2}{*}[1]{} & WK & 1 & & & \\
\hline & & $\mathrm{p}$ & & & & \\
\hline & \multirow[t]{2}{*}[2]{} & WK &,$- 817^{* *}$ & 1 & & \\
\hline & & $p$ & 000 & & & \\
\hline & \multirow[t]{2}{*}[3]{} & WK &, $830^{* *}$ &,$- 987^{* *}$ & 1 & \\
\hline & & $p$ &, 000 & $\overline{0,000}$ & & \\
\hline & \multirow[t]{2}{*}{ [4] } & WK &,$- 830^{* * *}$ & ,987** & $-1,000^{* *}$ & 1 \\
\hline & & $p$ & 000 &, 000 & & \\
\hline
\end{tabular}

[1] Uczniowie publicznych szkół podstawowych (bez specjalnych).

[2] Uczniowie niepublicznych szkół podstawowych (bez specjalnych).

[3] Publiczne szkoły podstawowe (bez specjalnych).

[4] Niepubliczne szkoły podstawowe (bez specjalnych).

WK - współczynnik korelacji (przyjmuje wartość od -1 do 1; wyższa bezwzględna wartość świadczy o większej sile zależności).

$\mathrm{p}$ - istotność dwustronna.

** Korelacja jest istotna na poziomie 0,01 (dwustronnie).

Źródło: opracowanie własne.

powszechna praktyka wykorzystywana w badaniach ekonomicznych [Bratnicka, Dyduch, 2014, s. 183, 188; Jegorow, 2014, s. 166-167; Jegorow, 2017c, s. 70; Kuszewski, Sielska, 2010, s. 156; Porzak, Sagan, 2013, s. 190; Walesiak, 2002, s. 118; Węgrzyn, 2014, s. 265; Mika, Siejka, 2013, s. 116].

5 Test zakłada normalność rozkładu zestawionych zmiennych i występowanie związku liniowego. Współczynnik najczęściej jest wykorzystywany w analizach społecznych.

6 Test jest oparty na współczynniku korelacji Pearsona. Liczony jest dla rang zmiennych. Charakter monotoniczności nie jest określony a priori. Współczynnik jest stosowany przy dowolnym rozkładzie porównywanych zmiennych. Korelacja rang jest „odporną” wersją klasycznego współczynnika korelacji Pearsona.

7 Na ogół test służy do opisu korelacji między zmiennymi porządkowymi lub rangowymi. Stosowany jest również jako alternatywa dla współczynnika korelacji Pearsona w przypadku braku spełnienia wymagań wejściowych. 
Podobnie jest w przypadku przedszkoli. Udział placówek niepublicznych w latach 1998-2015 zwiększył się z 6,10\% do 39,45\%. Równolegle liczba dzieci uczęszczająca do tych przedszkoli zwiększyła się z 4,53\% do 23,91\% [Bank Danych Lokalmych, 2016]. Oczywiście powyższe zmiany ilościowe są pochodną nie tylko celowego włączania się w aktywność gospodarczą opartą na względnie trwałych transferach finansowych, a często wynikają wprost z zagospodarowywania przestrzeni publicznej w obszarach, w których instytucje państwa są niewydolne.

To, że na arenie krajowej powstają nowe partie polityczne, należy łączyć z naturą procesów demokratycznych. Jednocześnie należy pamiętać, że permanentna walka o głosy wyborców, zwłaszcza w wyborach parlamentarnych, poza dążeniem do przejęcia władzy, to również szansa na zdobycie subwencji pozwalających na utrzymywanie lub budowanie struktur organizacyjnych. Ma to swoje uzasadnienie nawet w sytuacji zaciagania indywidualnych czy grupowych zobowiązań finansowych na poczet potencjalnych wpływów z przyszłych kadencji. Partie polityczne w wymiarze operacyjnym mają charakter projektów biznesowych, w przypadku których zdobycie środków publicznych jest przejawem racjonalnego działania nastawionego na konkretne korzyści ekonomiczne.

Nie brakuje przykładów prywatnych instytucji kultury, które czerpiąc z dotacji samorządowych lub rządowych, prowadzą formalnie niezależną działalność. Mimo to samodzielności organizacyjnej nie można w takich przypadkach łączyć z samowystarczalnością finansowa. Powstały konstrukt gospodarczy został obarczony podstawowa wadą wpisaną w uznaniowe zatwierdzanie dotacji. Niejednokrotnie okazywało się bowiem, że odmowa finansowania biorców pomocy publicznej na rzecz dofinansowania innych podmiotów łączyła się z pojawieniem się poważnych problemów finansowych, a w skrajnych sytuacjach upadkiem prowadzonej działalności. Należy w tym miejscu zaznaczyć, że na krajowym rynku funkcjonują liczne, prywatne instytucje kultury niezależne finansowo od środków publicznych.

Szczególne miejsce w zagospodarowywaniu środków publicznych na przestrzeni ostatnich lat należy przypisać organizacjom pozarządowym. Prowadząc działania w różnych obszarach aktywności społecznej i gospodarczej, podmioty te systematycznie zwiększały swój udział w rynku, zarówno w wymiarze ich liczby, jak i zakresu realizowanych działań [Jegorow, 2017a; Jegorow, 2017b]. Jednak rozwój sektora pozarządowego nie zawsze wynikał z realizacji założonej misji, ale nierzadko był efektem jego komercjalizacji przy jednoczesnym wzroście przychodów wpisanych w dotacje publiczne [Buttler, 2009, s. 142-143].

\section{Podsumowanie}

Poszukiwanie okazji do aktywności biznesowej jest wpisane w istotę przedsiębiorczości. Zatem zagospodarowywanie funduszy publicznych w ramach aktywności zawodowej jest naturalną konsekwencją wprowadzanych rozwiązań systemowych zorientowanych na bezpośrednie wsparcie finansowe podmiotów gospodarczych. Okazuje się, że w wielu przypadkach potencjalny dostęp do stałych publicznych transferów finan- 
sowych stał się w ostatnich latach kluczową determinantą podejmowania aktywności zawodowej, w tym również biznesowej. Środki publiczne, trafiając do sektora prywatnego, tracą swój publiczny charakter, tym samym co do zasady przy ich wydatkowaniu nie obowiązują zasady: celowości, efektywności i oszczędności pod rygorem odpowiedzialności. Jednak nie oznacza to pełnej swobody przy ich wydatkowaniu, choć obowiązujące $\mathrm{w}$ tym zakresie regulacje należy określić jako bardziej liberalne w stosunku do zasad wpisanych w instytucje sektora publicznego.

Nowy model gospodarowania, wpisany w przedsiębiorczość zależną od funduszy publicznych, został wykreowany na bazie interwencjonizmu włączającego podmioty prywatne do realizacji zadań, których inicjatorem lub gwarantem jest państwo. Przyjęty model rozwoju znamienny dla polskiej gospodarki ma swoje głębokie umocowanie w polityce gospodarczej Unii Europejskiej. Na gruncie rozważań naukowych sprzeczność w układzie: gospodarka rynkowa, konkurencja oraz interwencjonizm oparty na subsydiach i dotacjach ma empiryczne potwierdzenie, lecz dorobek badawczy w tym zakresie jest nieznaczny. Tymczasem aktualne założenia krajowej oraz wspólnotowej polityki gospodarczej systematycznie poszerzają zakres i formy dotowania przedsięwzięć prywatnych. Przyjmowane w tym obszarze założenia bardzo często odwołują się do potrzeby pobudzania przedsiębiorczości, co z kolei jest łączone z koniecznością wsparcia kapitałowego oraz przenoszeniem obszarów aktywności gospodarczej z poziomu publicznego na prywatny. Koncepcja ta niemal wprost zaprzecza teoretycznemu modelowi rozwoju Schumpetera.

Jednym z ważnych wymiarów przyjętych rozwiązań jest m.in. realizacja zadań z zakresu edukacji i ochrony zdrowia, a zwiazzane $z$ tym skuteczne konkurowanie bezwzględnie stałych i zdefiniowanych wysokości i form transferów finansowych na krajowym rynku jest aktualnie bardzo trudne. Podobnie polscy rolnicy bez dopłat bezpośrednich nie przetrwaliby na wspólnotowym rynku, przegrywając z producentami od lat wykorzystującymi doplaty bezpośrednie. Systemowe rozwiązania wkomponowane w przestrzeń społeczno-gospodarczą dały asumpt do uruchomienia wielu nowych podmiotów gospodarki narodowej lub podjęcia nowej aktywności zawodowej ze swojej natury zależnych od bezzwrotnych transferów finansowych. Powstały na tych założeniach nowy model biznesowy cieszy się dość dużą popularnościa, co uzasadnia potrzebę prowadzenia badań w tym zakresie z określeniem skutków w wymiarze mikroekonomicznym z implikacjami na wymiar makroekonomiczny w ujęciu dynamicznym.

\section{Literatura}

Bank Danych Lokalnych, 2016, Główny Urząd Statystyczny, Warszawa.

Bratnicka K., Dyduch W., 2014, Strategiczna przedsiebiorczość: koncepcja i pomiar, Prace Naukowe Wałbrzyskiej Wyższej Szkoły Zarządzania i Przedsiębiorczości, 27(2).

Buttler D., 2009, Ekonomia sektora nonprofit krytyka i reinterpretacja nybranych aspektów teoretycznych, „Ruch Prawniczy, Ekonomiczny i Socjologiczny”, LXXI(4).

Cieślik J., 2014, Przedsiebiorczość, politykea, rožnój, Wydawnictwo Akademickie SENDO, Warszawa. 
Czubak W., 2008, Rozdysponowanie dopłat bezpośrednich w gospodarstwach rolnych koraystajqcych z funduszy UE w Wielkopolsce, „Zagadnienia Ekonomiki Rolnej”, 4(317).

Glinka B., Gudkova S., 2011, Przedsiębiorczość, Wolters Kluwer, Warszawa.

Godłów-Legiędź J., 2010, Współczesna ekonomia. Ku nowemu paradygmatowi?, Wydawnictwo C.H. Beck, Warszawa.

Godłów-Legiędź J., 2017, Zasada rz̨adów prawa i przemiany ustrojowe w Polsce, „Gospodarka Narodowa", nr 3(89).

Jakimowicz A., 2012, Podstawy interwencjonizmu państwowego, Wydawnictwo Naukowe PWN, Warszawa.

Jegorow D., 2014, Polska gospodarka u progu 2014 roku - statystyczna analiza porównawcza w uktadzie miedzynarodowym oparta na wybranych wskaźnikach makroekonomicznych, „Nierówności Społeczne a Wzrost Gospodarczy”, nr 39(3).

Jegorow D., 2016, Uruchamianie działalności gospodarczej pray wsparciu dotacji a rozwój przedsiębiorczości, „Edukacja Ekonomistów i Menedżerów”, nr 3(41).

Jegorow D., 2017a, Ekonomizacja sektora pozarzadowego w Polsce, Zeszyty Naukowe Politechniki Śląskiej. Organizacja i Zarządzanie, nr 107 (w druku).

Jegorow D., 2017b, Organizacje pozarzqdowe jako przedsiebiorstwa zależne od funduszy europejskich, Zeszyty Naukowe Politechniki Śląskiej. Organizacja i Zarządzanie, nr 107 (w druku).

Jegorow D., 2017c, Przedsiebiorczość zależna jako celowy model biznesowy wpisany w bezzwrotne transfery finansowe, [w:] Projek.ty regionalne i lokalne - interesariusze projektu, H. Brandenburg, G. Tobor (red.), Wydawnictwo Uniwersytetu Ekonomicznego w Katowicach, Katowice.

Jegorow D., 2017d, Rozwój przedsiebiorczości indywidualnej pray wsparciu funduszy europejskich, Prace Naukowe Uniwersytetu Ekonomicznego we Wrocławiu, nr 475.

Kargol-Wasiluk A., 2008, Teoria dóbr publicznych a paradygmat ekonomii sektora publicznego, „Zarządzanie Publiczne”, nr 3(5).

Kautonen T., Down S., Welter F., Vainio P., Palmroos J., Althoff K., Kolb S., 2010, "Involuntary self-employment" as a public policy issue: a cross-country European review, "International Journal of Entrepreneurial Behavior \& Research", vol. 16, iss. 2, DOI 10.1108/13552551011027002.

Kuszewski T., Sielska A., 2010, Użytecz̧na sz̨tuka rankingów ekonomiczno-społecznych, „Współczesna Ekonomia”, nr 1(13).

Lipińska I., 2010, Rola i funkcjonowanie wspólnot gruntowych we wspótçesnych warunkach gospodarczych, Zeszyty Naukowe Szkoły Głównej Gospodarstwa Wiejskiego w Warszawie. Problemy Rolnictwa Światowego, nr 10(4).

Measuring Globalisation. OECD Handbook on Economic Globalisation Indicators, 2015, OECD, Paris.

Mika M., Siejka M., 2013, Badanie zależności pomiędzy różnica powierz̧chni katastralnej i ewidencyjnej, a jej wartościq ustalonq na podstawie przecietnych cen transakcyjnych na prayk.ładzie wybranych jednostek ewidencyjnych miasta Krakowa, „Infrastruktura i Ekologia Terenów Wiejskich", nr 2/II.

Miłaszewicz D., 2005, Wielkość państwa i jego jakość na praykeladzie polskiej gospodarki, Zeszyty Naukowe, Polskie Towarzystwo Ekonomiczne, nr 3. 
Miłaszewicz D., 2014, Problemy spotecznej efektywności sektora publicznego, „Studia Ekonomiczne", nr 180(2).

Ministerstwo Finansów, 2016, Zestawienie transferów finansowych środków unijnych od poczatku członkostwa Polski w UE (stan na koniec października 2016 r.), Warszawa.

Piecuch T., 2013, Przedsiębiorczość. Podstawy teoretyczne, Wydawnictwo C.H. Beck, Warszawa.

Porzak R., Sagan M., 2013, Nadzieja i przedsiębiorczośc-psychologiczne aspekty zarzqdzania, Zeszyty Naukowe WSEI seria: Ekonomia, nr 6(1).

Skica T., 2010, Efektywnośc wydatkowania publicznego w Polsce, Zeszyty Naukowe Wydziału Nauk Ekonomicznych Politechniki Koszalińskiej, nr 14.

Sobiecki R., 2015, Interwencjonizm w rolnictwie: dlaczego jest konieczny?, „Kwartalnik Nauk o Przedsiębiorstwie", nr 2.

Stankiewicz W., 2012, Ekonomia instytucjonalna, Warszawa, http://www.pwsbia.edu.pl/ pliki/Waclaw_Stankiewicz_Ekonomika_Instytucjonalna_III.pdf (data wejścia: 11.02.2017).

Stiglitz J.F., 2004, Ekonomia sektora publicznego, Wydawnictwo Naukowe PWN, Warszawa.

Walesiak M., 2002, Propozycja nogólnionej miary odległości w statystycznej analizie wielowymiarowej, [w:] Statystyka regionalna w stu̇́bie samorzqdu lokalnego i biznesu, J. Paradysz (red.), Wydawnictwo Akademii Ekonomicznej w Poznaniu, Poznań.

Węgrzyn T., 2014, Analiza korelacii pomiędzy wybranymi wskaźnikami finansowymi na prayykładrie spótek publicznych, „Studia Ekonomiczne”, nr 207.

Woźniak M.G., 2009, Instytucjonalne uwarunkowania wzrostu gospodarczego i sprawiedliwych nierówności społecznych, „Nierówności Społeczne a Wzrost Gospodarczy”, nr 14.

Woźniak M.G., 2017, W spółczesne niedostosowania instytucjonalne z.perspektywy wyzumań rozwojowych Polski, „Nierówności Społeczne a Wzrost Gospodarczy”, nr 50 (2).

Wyrozębska A., Matysiak A., Tatara T., Jurkowska U., Dmoch-Gajzlerska E., 2012, Badanie postaw przedsiebiorczych młodych pracowników ochrony zdrowia w dobie restrukturyzacji systemu opieki zdrowotnej w Polsce, „Hygeia Public Health”, nr 47(3).

Wyrozębski P., Wyrozębska A., 2012, Postawy przedsiębiorcze mtodych pracowników ochrony zdrowia $w$ dobie restrukturyzacji systemu opieki zdrowotnej w Polsce, [w:] Ekonomia, finanse $i$ zarzqdzanie w swietle nowych wyzwań gospodarczych, Ł. Woźny (red.), Oficyna Wydawnicza Szkoły Głównej Handlowej, Warszawa. 